\title{
The Role of Information and Communication Technology Inheritance of Local Wisdom Values of Minangkabau Culture: Speech Acts of Minangkabau Cultural Leader
}

\author{
Aprili Yanti $^{1}$, Khairina Nasution ${ }^{2}$, Oktavianus ${ }^{3}$, Mulyadi ${ }^{4}$ \\ ${ }^{1}$ Doctoral Program of Linguistics, Faculty of Cultural Sciences, ${ }^{2,4}$ University of North Sumatera, \\ Medan, Indonesia, Faculty of Cultural Sciences, University of North Sumatera, Medan, Indonesia, \\ ${ }^{3}$ Faculty of Cultural Sciences, Andalas University, Padang, Indonesia \\ *apriliyanti.linguistics@gmail.com
}

\begin{abstract}
This study aims to describe the role and usefulness of communication and information technology in the inheritance of local wisdom values of Minangkabau culture in the speech of the Minangkabau cultural leader in the context of the "Pitaruah Ayah" Monologue Speech. The role of information technology in the field of socioculture has a positive contribution as a mediation of the existence of Minangkabau cultural leaders to their people in carrying out their functions from this speech can be heard globally by the Minang generation. This study used the illocutionary speech act theory presented by Searle and the values of local wisdom by Octavian. This research uses descriptive qualitative method with the ethnographic approach. The data were taken in the form of recorded speech used by Minangkabau cultural leaders in the form of data transcription and strengthened by in-depth. The findings of this study are (1) The role of information communication technology in maintaining and inheriting local wisdom of Minangkabau culture (2 ) Speech actions used by Minangkabau cultural leaders in the form of assertive, directive and declarative (3) The power of the language delivered has a function as informative, supervise, directive persuasive and non-dominative or egalitarian. (4) The local wisdom values of Minangakabau culture passed on to the Minang generation are the values of religiosity.
\end{abstract}

Keywords: Technology; Local Wisdom; Cultural Leader; Speech Acts

\section{Introduction}

The pandemic of Covid-19 outbreak shocked the world community with the limitation of social distance requiring virtual facing to facilitate social interaction and improve the standard of living. For people who do not have good preparation in the faith, science, mental and pandemic technology is a plague that can damage the order of human life and be eliminated from the competition of life. But for tough humans consider the pandemic of Covid-19 is a momentum for contemplation (contemplation) in improving themselves and reading great opportunities still exist in this situation. Especially the demands of his competence in using technology. The dynamics of accelerating technology and information so rapidly cannot be 
avoided. The global community is required to have intellectual intelligence and emotional intelligence to selectively filter the flow of this technology. Because technology can provide positive and negative influences that enter into the life both politically, economically, socially, culturally, education, health and even entertainment. Zoom webinars, Facebook, YouTube, Google, Instagram, Online Business, WA, Twitter, TikTok are just a few of the many applications offered by sophisticated information and communication technology. It's not that not many of these applications can change someone's life much better or get worse.

There are many examples we can see today such as someone whose level of religiosity has improved because of the religious share review from his community group, a researcher who wants to test the quality of his scientific studies through reputable international journals, a student who is looking for sources of reference through digital libraries, someone becomes a successful creative entrepreneur because of his online business ventures with high creative creations, online traveling business that explores and exposes world culture, one can get rich quick because of being a YouTuber, teaching and learning activities that are not interrupted during the pandemic of Covid-19 through virtual online meeting between students and lecturers, someone forms social capital in a particular community by looking for friendship on Facebook, someone who limited to consult with medical parties can be done through the online consultation application "Halo Doc" and many more. But ironically, not all people maximize the role of this technology properly, moral degradation, lifestyle hedonism, consumptive, cultural shock to popular culture, culture lack of the lack of the treasury of religious knowledge, so that it damages the values of local wisdom that was inherited by the ancestors who should occupy humans as a dignified nation. The wealth of values inherent in local wisdom cannot prevent the entry of global cultural assimilation.

According to Alfian, local wisdom is a view of life and knowledge as well as a life strategy that manifests activities carried out by local people in meeting their needs and is a collectivity of high-cultural wisdom of a nation that is passed on from generation to the next generation [1]. Jung, an analytical psychologist said that in assessing a person's personality can be seen from a hereditary inheritance from his ancestors or so-called collective unconscious [2]. Minangkabau speakers are one of the ethnic groups in Indonesia that are rich with local wisdom that can be observed through the language that has two main elements, namely (a) obliged to protect other individuals; (b) maintain creativity based on the Adagium " Adat Basandi Syara ', Syara' Basandi Kitabullah" and the philosophy "Alam Takambang Menjadi Guru" [3]. This pattern is shaped by stale baso basi and Islamic teachings that are adopted by the majority of the Minangkabau people who are inherent in Kato Nan Ampek's speech art. And individuals who have a large role are obliged to protect, advice one of their people is a leader. The Minangkabau leader is expected to be a parameter for the success of character building for his people and nephews [4], [5].

The speech of the Minangkabau cultural leader in the context of the monologue speech is one of the containers of information and communication that connects emotional attachment to find the spirit to know the Minangkabau culture between mamak and kemanakan. The ability of Minangkabau cultural leaders is considered mastering the problem of religion, understanding traditional teachings, having a broad cognition of knowledge and insight, linguistic stylistic intelligence creates good verbal communication so that the message of the speech can be received both by the nephew and his people. A leader becomes a role model in a society, credibility of the figure is needed polite words, charismatic, intelligence in the choice of diction on the speech delivered must be in sync with their daily behavior.

Pitaruah Ayah is a program in the form of a monologue speech which is spoken by a cultural master Minang also Cultural Leader named Yus Datuk Parpatih. He is a very 
influential and legendary Minang artist who has many masterpieces including a Minangkabau studio named Balerong. Several forms of Minang art offered by the Balerong studio in the form of rabab, talempong, Minangkabau drama and many more. However, Pitaruah Ayah is of particular concern by researchers because it is a monologue speech. Choosing the name "Pitaruah Ayah", Datuk Parpatih wanted to show his language politeness by submitting his humility as a father not as a leader. The call 'Father' wants to get close, not to make distance between the audience. The speaker is addressed to young people as the nephew of a mamak. "Pitaruah Ayah" is one of the programs of Balerong under the tutelage of Yus Datuk Parpatih to experience the recording industry revolution which has long been broadcasted on the radio and made in the form of cassettes then pieces of CDs and now it has been displayed on YouTube. Some of the topics offered by the "Pitaruah Ayah" monologue include polemics on daily life, how a father is responsible for giving advice, advice in delivering his son to being appointed as the head of his people, migrated to the land of people, Minang personality inheritance that departs from the history, culture and identity of the Minang people as well as religious issues and others. This monologue speech program was packaged in polite and metaphorical ways and did not impress the arrogance of his position. This goal was full of meaning with local wisdom of the Minang culture which had relevance resting on religiosity.

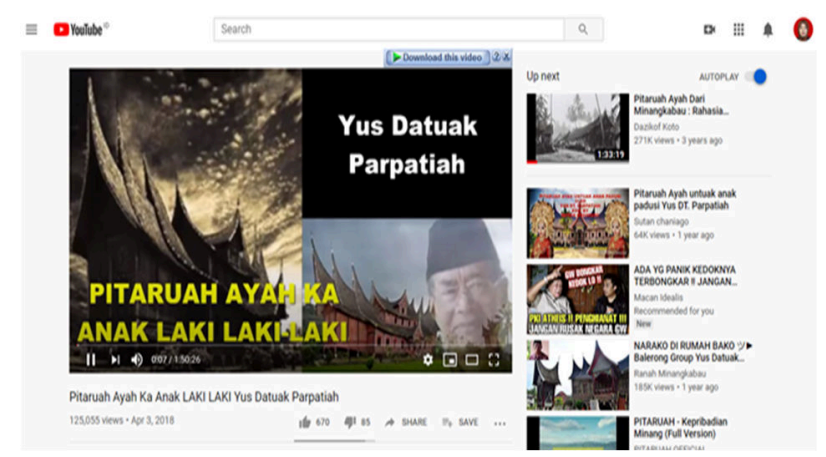

Figure 1. The illustration of "Pitaruah Ayah-Yus Datuak Parpatiah" in YouTube

The formulation of the problem that forms the basis of this research is how is the role of information and communication technology on the inheritance of local wisdom values of Minangkabau culture in the speech of the Minangkabau cultural leader in the context of the monologue speech "Pitaruah Ayah"?

\section{Literature Review}

The Ministry of Research and Technology states that information and communication technology (ICT) as part of science and technology (IPTEK) which in general is all technology related to the collection, collection, processing, storage, distribution, and presentation of information. According to research by "We Are Social", a British media company that works with Hootsuite, the average Indonesian spends 3 hours 23 minutes a day to access social media. From a report entitled "Essential Insights into the Internet, Social Media, Mobile, and E-Commerce Use Around the World" published January 30, 2018, of 
Indonesia's total population of 265.4 million, active users of social media reached 130 million with penetration 49 percent. As many as 120 million Indonesians use mobile devices, such as smartphones or tablets to access social media, with 45 percent penetration. Within a week, online activity on social media via smartphones reached 37 percent. In order from the first position are WhatsApp, Facebook, Instagram [6]. The use of the internet as social media is expected to use appropriate, effective and polite speech that can be understood and provide better change for many people.

Pragmatics are conditions of language use that are determined by the context of the community that involve speakers and speech partners in certain uses that function to interpret the intentions, goals and assumptions of people from various types of speech acts, understand the speech of others in the thinking of the person, represent one's mental state. All speech speakers are considered as an action [7], [8]. And the ability to investigate how the listener concludes what is said to get the interpretation of the meaning intended by the speaker, more interpreting of what is spoken, examines the structure of language externally used in communication. Speech selection strategies in interaction have the intention of facilitating the message delivered. Pragmatic power has the power of the message implicit in an utterance. Pragmatics is closely related to a context in understanding the meaning of speech speakers that refer to situations (spatial) and time (temporal) that cannot be avoided social and cultural context based on shared knowledge between speakers and speech partners. Searle divides illocutionary speech acts into 5 namely assertive, directive, expressive and declarative. Each speech has a different purpose and purpose by the speaker that is expected to be understood by the speech partner so as to create a smooth communication because they maintain the comfort of the speech partner's face [9].

\section{Methodology}

This study uses a qualitative descriptive approach that looks at ethnographic phenomena that are homogeneous communities. This research method refers to the theory of Sudaryanto with matching techniques and data analysis [10]. The data was taken from the recorded speech of the cultural leader of the Minangkabau, namely Yus Datuk Parpatih in the context of the monologue speech "Pitaruah Ayah" in the form of data transcription and the grouping of data was made according to a research study. The basis of this data analysis is to use Searle's theory in speech acts and hermeneutic studies in interpreting the local wisdom values of Minangkabau culture as reflected in his speech.

\section{Result and Discussion}

\subsection{Values of Religiosity}

Religiosity is the internalization of religious values in a person. Internalization related to belief in religious teachings both in the heart and in speech. This belief is then actualized in daily actions and behavior in the form of ideological dimensions, practices, experiences, knowledge, religious consequences [11]-[13]:

(1) Nasi sarimah nan basuok, aia satitiak nan bataguak, piti kupang ka balanjo, kain sabanang nan dipakai ikua di jalan Allah, bacampua barang haram sadonyokan 
ditanya nak sadonyo, kan diuji kan disasekan dipareso dimeja hijau dihadapan Allah kan bajaya "kulukum rain wakulukum rain masula roiya".(everything that is owned, used, the deed will be held accountable from God)

(2) Nafsu sabagai rahmat adalah anugerah Allah ta'ala yang tak dapek di malaikat patuiklah disukuri malalui nikah parkawinan inilah lataknyo kamulian, nak. Sinilah kataqwaan mancari darajat jo martabat insan sajatinyo. Tapi kok ndaklah jalan nan pasa batampuah labuhan bagolong baturuik mambali barang baecer ba nio dipakai maminjam basuko-suko alamek panyakit, kamuliaan nan tangguanglah aib.(marriage is worshipped to endure lust)

These words are directive advice Speech (1) about "To be tested and pared on the court before God" is a proof of the speech of speakers who believe in the existence of God. The God's court is the end of the world a human responsibility for what he does while living in the world. This statement is expressive of innuendo. Speech (2) about Minangkabau culture is a very adaptive culture, easy to adjust to the environment in order to avoid a conflict. In adjusting to the environment, trying not to make a disgrace that can embarrass the village and its heritage. The Minang philosophy that leads the Minang community to adapt well to their environment is contained in the Minang proverb "Dima bumi dipijak disiko langik dijunjuang". The concept of marriage in the principle of Islamic Sharia is marriage is a worship and legally married can be said to be mandatory if you have the will and willingness to marry to protect yourself and avoid prohibited conduct. This statement is assertive advice.

\subsection{Values of Character Building}

Character education is an educational process based on local wisdom that can reflect local values in fostering a sense of love for their own culture in developing civic culture in various contexts as a form of long-life education [14], [15].

(1) Adat manyuruh akal sehat, agama urang barakal mako batamolah ruweh jo kukuah bak kuncua ka hulu elok tibo dirancak manantilah samao santiangnyo (Adat does not contradict religious values)

(2) Mangecek malihek-lihek, bagara maagak-agak, bacaruik sakali jangan, nampakan wibawa ke nan ketek, samo gadang baso-basi, mulia nan tuah, baotah samakin dareh. (Use the politeness communication and respect eah other, apply the Kato nan Ampek)

Speech (3) about Minangkabau Adat does not contradict Islamic teachings because Minangkabau Adat refers to Islam, showing character education to be able to think critically, trying to analyze logically from new information that is not easy to believe without being first examined by deepening its knowledge. Trying to compare and negotiate with people who are experts in their fields that do not conflict with the values of Islamic law. This statement is assertive the claim that Minang custom is in line with Islamic values. This statement shows character education to be able to think critically, try to analyze logically from new information is not easy to believe without first reviewing the truth by deepening knowledge. This speech is directive in the form of advice. Speech (4) about the key to success in interacting with others is being clever in polite speech, all the words we say will leave an impression on those who hear it, can respect the older, love the younger, and respect each other with peers. This statement is an advice directive. 


\section{Acknowledgment}

My appreciation is addressed to University of North Sumatera, that allowed and provided me a nice opportunity to pursue good education at Doctoral Program of Linguistic, University of North Sumatera.

\section{References}

[1] M. Alfian, "Potensi Kearifan Lokal dalam Pembentukan Jati Diri dan Karakter Bangsa," 2013.

[2] C. G. Jung, Memperkenalkan Psikologi Analitik. Jakarta: Gramedia, 1989.

[3] M. Abidin, Implementasi adat basandi syarak, syarak basandi kitabullah. Padang: Pusat Pengkajian Islam dan Minangkabau (PPIM), 2004.

[4] M. S. Amir, Pola dan Tujuan Hidup Orang Minang. Jakarta: PT. Mutiara Sumber Widya, 1999.

[5] A. A. Navis, Alam Terkembang Jadi Guru: Adat dan Kebudayaan Minangkabau. Jakarta: Grafiti Press, 1984.

[6] Kompas.com, "Riset Ungkap Pola Pemakaian Medsos Orang Indonesia," https://tekno.kompas.com/read/2018/03/01/10340027/riset-ungkap-pola-pemakaianmedsos-orang-indonesia?, 2020 . https://tekno.kompas.com/read/2018/03/01/10340027/riset-ungkap-pola-pemakaianmedsos-orang-indonesia?

[7] F. Gunawan, "Wujud Kesantunan Berbahasa Mahasiswa Terhadap Dosen di STAIN Kendari: Kajian Sosiopragmatik," J. ARBITRER, vol. 1, no. 1, p. 8, Oct. 2013, doi: 10.25077/ar.1.1.8-18.2013.

[8] B. B. Frey, "The SAGE Encyclopedia of Educational Research, Measurement, and Evaluation," The SAGE Encyclopedia of Educational Research, Measurement, and Evaluation, Feb. 22, 2018. .

[9] Searle, Speech Acts an Essay in The Philosophy of Language. Oxford: Basil Blackwell, 1979.

[10] Sudaryanto, Metode dan Aneka Teknik Analisis Bahasa, Pengantar Penelitian Wahana Kebudayaan Secara Linguistik. Yogyakarta: Duta Wacana University Press, 2015.

[11] C. Y. Glock and R. Stark, Religion and society in tension. San Fransisco: Rand McNally, 1965.

[12] L. D. Pearce, G. M. Hayward, and J. A. Pearlman, "Measuring Five Dimensions of Religiosity Across Adolescence," Rev. Relig. Res., vol. 59, no. 3, pp. 367-393, Sep. 2017, doi: 10.1007/s13644-017-0291-8.

[13] Y. El-Menouar and B. Stiftung, "The Five Dimensions of Muslim Religiosity. Results of an Empirical Study," vol. 8, no. 1, pp. 53-78, 2014, doi: 10.12758/mda.2014.003. 
[14] S. A. Kamaruddin, "Character Education and Students Social Behavior," J. Educ. Learn., vol. 6, no. 4, pp. 223-230, 2012.

[15] N. Novianti, "Teaching Character Education to College Students Using Bildungsromans," Int. J. Instr., vol. 10, no. 4, pp. 255-272, 2017, doi: 10.12973/iji.2017.10415a. 